\title{
Consumer Preferences and Socioeconomic Factors Decided on Plantain and Plantain-Based Products in the Central Region of Cameroon and Oyo State, Nigeria
}

\author{
Patchimaporn Udomkun ${ }^{1, * \mathbb{D}}$, Cargele Masso ${ }^{2}$, Rony Swennen ${ }^{3,4}$, Bhundit Innawong ${ }^{5}$, Apollin Fotso Kuate ${ }^{2} \mathbb{D}$, \\ Amos Alakonya ${ }^{6} \mathbb{D}$, Jules Lienou ${ }^{2}$, Dorcas Olubunmi Ibitoye ${ }^{7}$ and Bernard Vanlauwe ${ }^{8}$ \\ 1 International Institute of Tropical Agriculture (IITA), Bujumbura 1893, Burundi \\ 2 IITA, Yaoundé BP 2008, Cameroon; C.Masso@cgiar.org (C.M.); A.Fotso@cgiar.org (A.F.K.); \\ J.Lienou@cgiar.org (J.L.) \\ 3 IITA, Kampala 7878, Uganda; R.Swennen@cgiar.org or rony.swennen@kuleuven.be \\ 4 Department of Biosystems, KU Leuven, 3001 Heverlee, Belgium \\ 5 Department of Food Technology, Faculty of Engineering and Industrial Technology, Silpakorn University, \\ Nakhon Pathom 73000, Thailand; b.innawong@gmail.com \\ 6 International Maize and Wheat Improvement Center (CIMMYT), Texcoco 56237, Mexico; \\ A.Alakonya@cgiar.org \\ 7 National Horticultural Research Institute (NIHORT), Ibadan 5432, Nigeria; bunmiajisafe@yahoo.com \\ $8 \quad$ IITA, Nairobi 30772-00100, Kenya; B.Vanlauwe@cgiar.org \\ check for \\ updates \\ Citation: Udomkun, P.; Masso, C.; \\ * Correspondence: P.Udomkun@cgiar.org
} Swennen, R.; Innawong, B.; Fotso Kuate, A.; Alakonya, A.; Lienou, J.; Ibitoye, D.O.; Vanlauwe, B. Consumer Preferences and Socioeconomic Factors Decided on Plantain and Plantain-Based Products in the Central Region of Cameroon and Oyo State, Nigeria. Foods 2021, 10, 1955. https://doi.org/10.3390/ foods10081955

Academic Editors: Begoña Panea,

Francisco Javier Mesias and

Guerrero Luis

Received: 25 July 2021

Accepted: 19 August 2021

Published: 22 August 2021

Publisher's Note: MDPI stays neutral with regard to jurisdictional claims in published maps and institutional affiliations.

Copyright: (c) 2021 by the authors Licensee MDPI, Basel, Switzerland. This article is an open access article distributed under the terms and conditions of the Creative Commons Attribution (CC BY) license (https:// creativecommons.org/licenses/by/ $4.0 /)$
Abstract: Plantain is a key staple food in Central and West Africa, but there is limited understanding of its market in Africa. In addition, the cooking methods for enhancing the nutritional value, consumer preference, and willingness to pay for plantain and plantain-based products are not well understood. The knowledge gaps in the market and consumer dimension of the food chain need to be known to increase plantain utilization and guide breeding efforts. This research contributes by examining the cooking methods, consumer preference, and willingness to pay for plantain and plantain-based products in Cameroon and Nigeria. A household survey sample of 454 Cameroonian consumers in four divisions of Central Region and 418 Nigerian consumers in seven government areas of Oyo State in southwest Nigeria was the basis for the analysis. The results showed some levels of similarity and difference in the consumption and cooking of boiled, roasted, and fried plantain in both countries. The trend in consumption of all plantain-based products was constant in Cameroon but increased in Nigeria. The most important factor influencing Cameroonian consumers' choice of plantain and its products was taste, while the nutrition trait influenced Nigerian consumers. Both Cameroonian and Nigerian consumers considered packaging, location of produce, and size and quantity as the least important factors. In addition, socioeconomic characteristics were significant determinants of consumers' choices to consume plantain and its products. Gender significantly influenced $(p<0.05)$ taste, while nutrition was significantly driven $(p<0.05)$ by education and annual income. Household size played a significant role $(p<0.05)$ in consumers' choices when the price was considered. These findings serve as a guideline to improve existing products to match the needs of consumers in each country and develop products for different consumer segments and potentially increase production.

Keywords: banana and plantain; consumer behavior; consumer choice; processed products; quality attributes; willingness to purchase

\section{Introduction}

Plantains are considered a good source of starch and energy in sub-Saharan Africa (SSA) [1] and are nutrient-rich in dietary fiber, minerals (potassium and phosphorus), vitamins (A, B1, B2, B6, and C), and phenolic compounds [2-6]. Unripe plantain has been 
documented as a hypoglycemic plant used in the management of diabetic complications [7] Ripe plantain contributes significantly to food security and provides a daily intake of more than $25 \%$ of carbohydrates and $10 \%$ of calories for more than 70 million people in sub-Saharan Africa [8,9]. However, the availability and concentration of those chemical constituents vary with the cultivar, postharvest maturation, growing location, climate, and agricultural practices [10-12]. Apart from playing an important role in addressing food security for over 500 million people in the SSA region, plantain also contributes to the subsistence economies in Africa [13] and generates considerable employment [14]. Marriott and Lancaster [15] reported that plantain cultivation is more lucrative to farmers than cassava, maize, rice, or yam due to lower labor requirements. The main plantain producing regions are Central (42\%) and West (40\%) Africa, accounting for approximately $60 \%$ of worldwide production [16]. During 2010-2019, plantain production increased by $36.7 \%$ in Central Africa and 20.8\% in West Africa. The highest plantain-producing countries in Central Africa are the Democratic Republic of Congo and Cameroon, whereas Ghana and Nigeria are two major producers in West Africa.

As postharvest maturation affects the ripening rate, plantain is mostly harvested green at different maturity stages depending on the distance to markets [17]. Depending on the consumer, plantain is eaten fresh at the ripened stage or is locally processed into different dishes, depending on the ripening stage [18] and the custom of the ethnic group [19]. In Cameroon, plantain plays an important role in family events such as weddings, funerals, and the celebration of a newborn child, particularly in the South. Sometimes, the plantain in a meal is compulsory [20-22]. Plantain is also a main ingredient in Nigerian cuisine; Nigerians often prefer plantain for breakfast $[23,24]$. In addition, commercial production of plantain-based products such as chips and flour has been developed in both countries [20]. Data from FAOSTAT [16] shows that the quantity of plantain for processing increased tremendously by $382 \%$ in Cameroon during 2003-2013. Adeoye and Oni [25] linked the increase in demand for raw plantain in Nigeria to more local processing industries.

Although the current demand for plantains and their products is high, consumers' needs and tastes change over time [26]. Understanding consumers' trait preferences is the first step in developing a demand-driven breeding program. In addition, knowledge of traits that consumers prefer will enable researchers and farmers to produce marketable cultivars with acceptable attributes. In the case of producers, it is critical to know what consumers like or dislike about existing products [27] to innovate a product successfully. In general, consumer preferences are conditional on both intrinsic and extrinsic factors [28-30]. $\mathrm{Li}$ et al. [31] explained that intrinsic factors are those that cannot be altered without physically changing the composition of the product, such as color, aroma, texture, and so on. Extrinsic factors can influence consumer choice and include the brand, price, packaging, label claims, perceived satiety, emotional response, decision-making process, and the emotional impact often influenced by culture. Therefore, actors in the plantain value chain who understand the factors influencing consumer preferences will be able to identify the impact on consumers' purchasing decisions [32-34], particularly when food products are becoming more complex owing to consumers' demands [35]. There is evidence that producers who engage in value addition in agricultural value chains are often faced with competition from experienced competitors who have established networks of consumers [36].

However, scientific information about consumers' needs and preferences of plantain and their products is still limited, as few studies have been reported. A better understanding of such information is needed to enhance the adoption, production, and utilization of plantain products in Cameroon and Nigeria. In this paper, therefore, the characteristics of Cameroonian consumers in the Central Region and Nigerian consumers in Oyo State regarding their perception towards plantain and plantain-based products were examined to seek ways to improve the quality of existing products and develop new ones. In particular, the study evaluated the consumption characteristics and investigated the effect of 
sociodemographic attributes or factors that influence consumers' choices for plantain and its products.

\section{Materials and Methods}

\subsection{Sampling and Survey Design}

A consumer survey was conducted between April and May 2020 in rural, peri-urban, and urban areas of Cameroon and Nigeria. In Cameroon, the Central Region was selected, while Oyo State represented the study area in Nigeria. As regions of Cameroon are in divisions and subdivided by districts, the selected divisions in Central Region were Mfoundi (districts: Yaoundé 1 and Yaoundé 6), Nyong et So'o (district: Mbalmayo), Nyong et Mfoumou (districts: Ngoumou, Akonolinga, and Ayos), and Mbam et Kim (district: Ntui) (Figure 1A). In Nigeria, each state is divided into local government areas (LGAs) and then subcommunities. The selected LGAs in Oyo State were Ona Ara (subcommunities: Olunloyo, Amuloko, Gbedun, and Akanran), Akinyele (subcommunities: Alabata, Ijaye, Ojedeji, Saanu, and Oladele), Egbede (subcommunities: Monatan, Olodo, Alakia, and Osegere), Ibadan-North East (subcommunities: Idi-Ape, Iwo, and Bashorun Oja), Ibadan-North (subcommunities: Yemetu, Oke Are, and Sango), Oluyole (subcommunities: Abanla, Idi Ayunre, and Elebu/Orita), and Ido (subcommunities: Ologuneru, Ile Tuntun, Apata/Odo Ona, and Elewe) (Figure 1B).

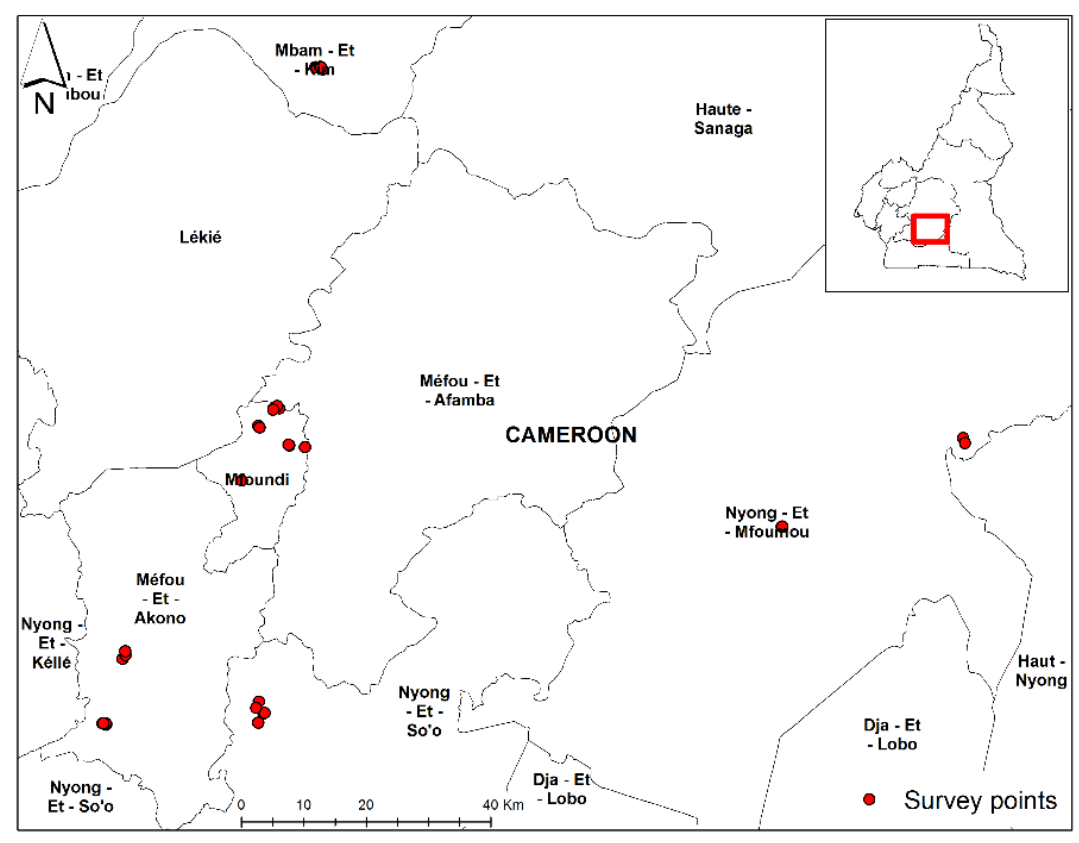

(A)

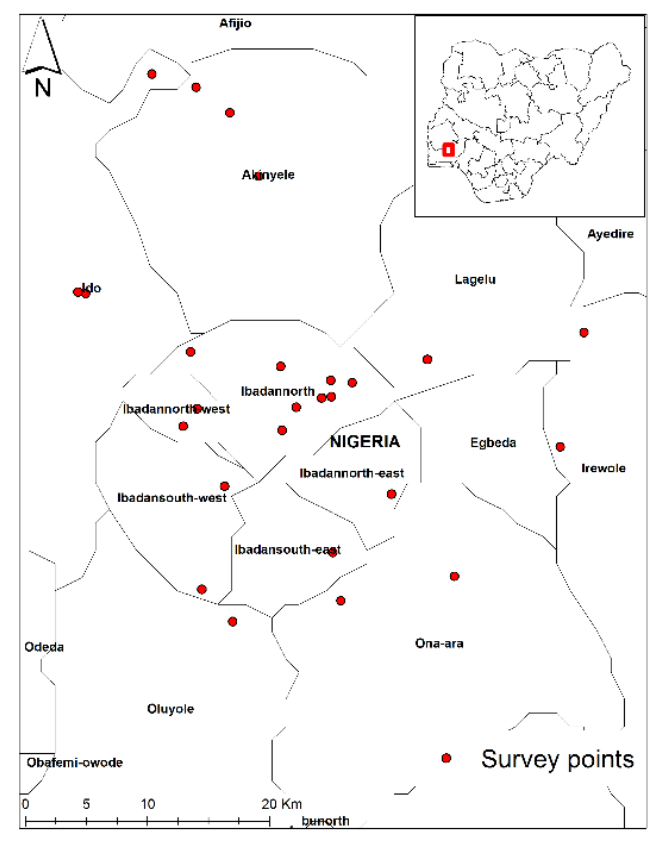

(B)

Figure 1. Sampling areas in Cameroon (A) and Nigeria (B).

A stratified multistage sampling procedure was used for data collection. In the first stage, region/state areas with high plantain production and consumption were listed; subsequently, districts/local government areas were randomly selected. In the second stage, the selected districts/local government areas were divided into blocks (production and processing/marketing areas), and blocks were randomly chosen from within each selected collection district/local government area. Within each selected block, a list of households was generated in the third stage, and some of them were retained based on probable proportional size. Lastly, a total sample was picked based on systematic sampling until the actual study of total households was sampled. After selection, face-to-face interviews with respondents were conducted by trained enumerators using a semistructured questionnaire administered in English and French according to their language of choice. 
Sociodemographic data was first collected from the respondents on area classification, gender, age, marital status, year of education, education level, household size, number of women and children below 5 years of age in household, annual household income, main sources of household income, household expenses, household expense for plantains, purchasing locations, and major sources of fuel and water supply for cooking.

From the survey data, the majority of Cameroonian respondents in the Central Region $(74 \%)$ and Nigerian respondents in Oyo State $(58 \%)$ lived in urban areas (Table 1). Overall, more females $(62 \%)$ responded than males with an average age of 40 years but varying between 18 to 90 years. The average household size was 7 persons in Cameroon and 5 in Nigeria, with approximately $40 \%$ of females and $16 \%$ of children below 5 years of age in households. About $59 \%$ of Cameroonian and $73 \%$ of Nigerian respondents were married and living with their spouses. The average year of education of respondents was 11.2 in Cameroon and 13.6 in Nigeria, with more than $40 \%$ of the respondents having secondary school certificates, while less than $15 \%$ of them had a university education. The total household annual income of most Cameroonian respondents (47\%) ranged between USD 1801 and 6000, while more than half of Nigerian respondents earned a household annual income that ranged from less than USD 600 to 1800. The main source of household income in Cameroon was crop sales (30\%), and in Nigeria, craftmanship (32\%). About half of household income was spent on food, and a third of that household food expenditure was used to purchase plantain. Gas was the main fuel for cooking in both Cameroon (45\%) and Nigeria (54\%). In Cameroon, 38\% of the respondents received water from pipes for cooking, while $52 \%$ of Nigerian respondents used water from wells.

Table 1. Socioeconomic characteristics of the respondents.

\begin{tabular}{|c|c|c|}
\hline \multirow{2}{*}{ Characteristics } & \multicolumn{2}{|c|}{ Country } \\
\hline & Cameroon $(n=454)$ & Nigeria $(n=418)$ \\
\hline \multicolumn{3}{|l|}{ Location of the household (\%) } \\
\hline Rural & 8.8 & 25.1 \\
\hline Urban & 74.4 & 57.7 \\
\hline Peri-urban & 16.8 & 17.2 \\
\hline Female respondents (\%) & 61.8 & 62.1 \\
\hline Average age (years) ${ }^{1}$ & $38.6(12.7)$ & $40.0(14.1)$ \\
\hline Household size (number) ${ }^{1}$ & $6.9(3.0)$ & $5.4(3.3)$ \\
\hline Women in household (number) ${ }^{1}$ & $3.0(1.7)$ & $2.1(1.8)$ \\
\hline $\begin{array}{l}\text { Children below } 5 \text { years of age in household } \\
\text { (number) }{ }^{1}\end{array}$ & $1.2(1.2)$ & $0.8(1.0)$ \\
\hline \multicolumn{3}{|l|}{ Marital status (\%) } \\
\hline Never married & 26.5 & 13.6 \\
\hline Married, living with spouse & 59.1 & 72.5 \\
\hline Married, spouse away & 2.4 & 4.5 \\
\hline Widow/Widower & 6.3 & 8.1 \\
\hline Other (Engaged, Separated, Divorced) & 5.7 & 1.3 \\
\hline Average education (years) ${ }^{1}$ & $11.2(4.5)$ & $13.6(5.2)$ \\
\hline \multicolumn{3}{|l|}{ Education level (\%) } \\
\hline None & 3.7 & 9.3 \\
\hline Primary & 23.8 & 17.9 \\
\hline Secondary & 41.0 & 47.1 \\
\hline Bachelor & 10.1 & 12.2 \\
\hline Master/Doctorate & 3.2 & 0.5 \\
\hline Other (Graduate, Religious, Adult education) & 0.4 & 13.0 \\
\hline \multicolumn{3}{|l|}{ Household annual income (\%) } \\
\hline$<$ USD 600 & 5.9 & 13.9 \\
\hline USD 600-1800 & 41.0 & 51.2 \\
\hline USD 1801-6000 & 46.5 & 28.4 \\
\hline >USD 6000 & 6.6 & 6.5 \\
\hline
\end{tabular}


Table 1. Cont.

\begin{tabular}{|c|c|c|}
\hline \multirow{2}{*}{ Characteristics } & \multicolumn{2}{|c|}{ Country } \\
\hline & Cameroon $(n=454)$ & Nigeria $(n=418)$ \\
\hline \multicolumn{3}{|l|}{ Main source of household income (\%) } \\
\hline Crop sales & 29.6 & 14.5 \\
\hline Craftmanship & 27.3 & 32.2 \\
\hline Part-time labor & 1.9 & 10.0 \\
\hline Permanent employment & 12.8 & 2.5 \\
\hline Pension & 14.7 & 16.1 \\
\hline $\begin{array}{l}\text { Others (Sales of livestock, Food processing, } \\
\text { Remittance, Others) }\end{array}$ & 6.7 & 7.7 \\
\hline Household expense for foods (within 10 parts) ${ }^{1}$ & $5.3(1.6)$ & $4.5(1.9)$ \\
\hline Household expense for plantains (within 10 parts) ${ }^{1}$ & $2.1(1.0)$ & $1.6(1.2)$ \\
\hline \multicolumn{3}{|l|}{ Main source of fuel for cooking $(\%)$} \\
\hline Charcoal & 13.6 & 7.2 \\
\hline Firewood & 38.6 & 17.6 \\
\hline Gas & 44.5 & 53.8 \\
\hline Others (Agricultural byproducts, Electricity) & 3.3 & 21.4 \\
\hline \multicolumn{3}{|l|}{ Major source of household water supply for cooking (\%) } \\
\hline Wells & 29.5 & 51.9 \\
\hline Borehole & 1.3 & 39.2 \\
\hline Water conveyance & 25.8 & 0.4 \\
\hline Pipe & 38.4 & 6.0 \\
\hline Others (River/Pond, Others) & 5.0 & 2.5 \\
\hline
\end{tabular}

${ }^{1}$ Value is the mean (standard deviation).

Subsequently, the respondents were asked about consumption frequency, consumption trends until now, cultivar commonly used, ripening stage used, cooking ingredients, common accompaniment, and cooking time of each plantain-based product (boiled, roasted, fried as chips, fried as dodo, flour, pounded, and porridge). Thirdly, the respondents were asked to rank the importance of certain factors (nutrition, food safety, taste, appearance, availability, price, size and quantity, packaging, advertisement, location of produce, and knowledge) in their choice to consume plantain-based products (Always $=1$; Sometimes $=2$; Never $=3$ ). Specifically, "food safety" was explained to the respondents as "food (plantain-based products) that will not harm anyone when it is prepared and/or eaten in accordance with the food's purpose". Later, the respondents were asked, "Have you ever purchased plantain products from the market?" If the respondents said "Yes", the enumerators continued by asking questions relating to their satisfaction with the products and main factors influencing their willingness to pay for new plantain products.

\subsection{Data Analysis}

STATA software version 12.0 (StataCorp. LP, College Station, TX, USA) was employed to analyze the data. Descriptive statistics were used to determine the means and frequencies of respondents' replies regarding collected data. Each ranked factor mean was computed to identify the most important factor. Chi-square $\left(\chi^{2}\right)$ and analysis of variance (ANOVA) were used to examine the differences in response from consumers. The Duncan Multiple Comparison Test ( $p<0.05$ confidence levels) was used for means comparison, and ANOVA tests were applied to relate the mean values with the consumers' socioeconomic characteristics to understand the factors influencing consumer's choice for plantain-based products.

\section{Results and Discussion}

\subsection{Consumption and Cooking Methods of Plantain}

In Cameroon, almost half of the respondents buy plantain and their products every month, while most Nigerian respondents buy plantain (52\%) and their products (37\%) every week (Figure 2a1,a2). Likewise, markets inside each community $(>60 \%)$ were the main source for buying fresh plantain and their products (Figure 2b1,b2). 

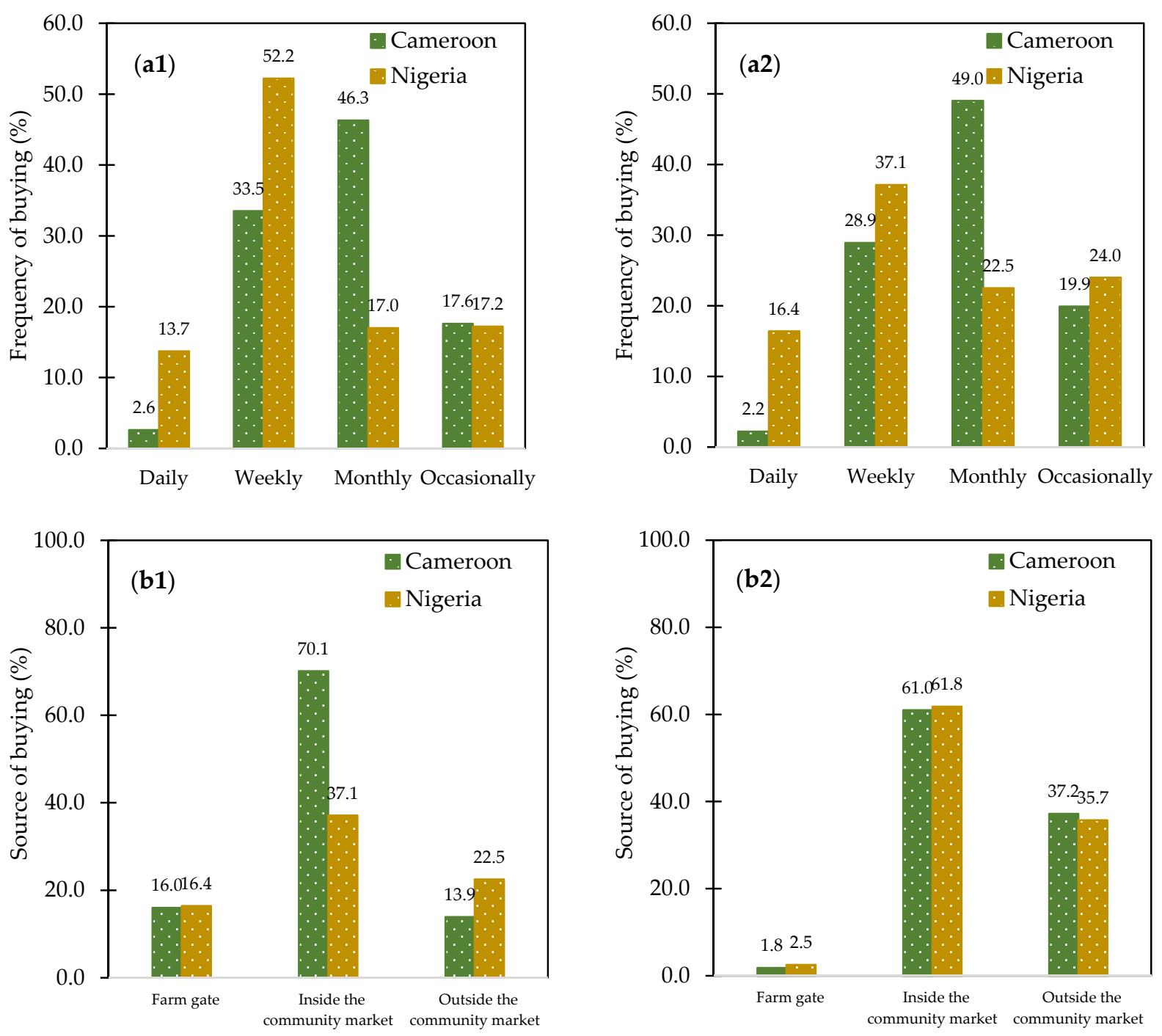

Figure 2. Frequency (a) and source (b) of buying fresh plantain (1) and plantain-based products (2) in Cameroon ( $n=454)$ and Nigeria $(n=418)$.

Plantain is usually prepared in different forms, such as boiled, roasted, fried, pounded, porridge, and flour, depending on the ripening stage [37]. The most commonly preferred dishes by the Cameroonian and Nigerian respondents were boiled and fried plantain as dodo, respectively (Tables 2 and 3). More than $40 \%$ of the Cameroonian and Nigerian respondents consumed boiled and fried plantain as dodo weekly; however, other plantainbased products were mostly consumed once a month. For boiled plantain, unripe or ripe plantain fingers are peeled and cooked in salted boiling water for 15-35 min. Boiled plantain are consumed with various sauces or other accompanying dishes. Fried plantain as dodo is processed by peeling and cutting into slices before frying in vegetable oil for about 8-10 min. Honfo et al. [19] and Okolle et al. [22] explained that the frying method is rapid and less time-consuming, and dodo could also be accompanied by various sauces, vegetables, and other food complements. These results agreed with Ayinde et al. [9], who reported that boiled and fried plantain represented the most important consumption form preferred by Nigerian households. 
Table 2. Consumption characteristics and cooking methods of plantain-based products in Cameroon.

\begin{tabular}{|c|c|c|c|c|c|c|}
\hline Products & $\begin{array}{l}\text { Boiled Plantain } \\
(n=420)\end{array}$ & $\begin{array}{l}\text { Roasted Plantain } \\
(n=162)\end{array}$ & $\begin{array}{l}\text { Fried as Chips }{ }^{2} \\
(n=327)\end{array}$ & Fried as $\operatorname{dodo}(n=350)$ & Pounded $(n=230)$ & Porridge $(n=269)$ \\
\hline \multicolumn{7}{|l|}{ Consumption frequency (\%) } \\
\hline 1 time/day & 0.7 & 1.2 & 1.2 & 0.6 & 0.4 & 0.0 \\
\hline Weekly & 50.7 & 29.4 & 39.4 & 43.7 & 28.3 & 27.9 \\
\hline Monthly & 40.5 & 38.0 & 43.7 & 41.4 & 44.3 & 49.4 \\
\hline Occasionally & 4.3 & 25.8 & 12.2 & 8.6 & 24.8 & 21.2 \\
\hline \multicolumn{7}{|l|}{ Consumption trend till now (\%) } \\
\hline Increasing & 28.1 & 25.9 & 27.0 & 24.6 & 25.5 & 25.7 \\
\hline Constant & 41.0 & 40.7 & 42.6 & 47.0 & 40.7 & 43.9 \\
\hline Decreasing & 31.0 & 33.3 & 30.4 & 28.4 & 33.8 & 30.5 \\
\hline Finger size commonly used & Small, Large & Small, Large & Small, Large & Small, Large & Small, Large & Small, Large \\
\hline \multicolumn{7}{|l|}{ Ripening stage (\%) } \\
\hline Matured green & 37.9 & 33.2 & 56.3 & 0.2 & 42.7 & 92.7 \\
\hline More yellow than green & 46.6 & 40.6 & 42.2 & 11.7 & 40.2 & 6.6 \\
\hline All yellow & 13.9 & 19.1 & 1.3 & 54.6 & 13.5 & 0.3 \\
\hline Yellow flecked with brown & 1.7 & 7.0 & 0.2 & 33.5 & 3.7 & 0.3 \\
\hline Common accompaniments & $\begin{array}{l}\text { Various sauces, beans, } \\
\text { cassava leaf, meats }\end{array}$ & $\begin{array}{l}\text { Vegetables, fruits } \\
\text { (avocado, plums, } \\
\text { pears), fish, meats }\end{array}$ & Beans, eggs, fish, meats & $\begin{array}{l}\text { Eggs, fish, meats, } \\
\text { vegetable sauces, ugali }\end{array}$ & Various sauces & - \\
\hline Cooking time $(\mathrm{min})^{1}$ & $33.6(12.0)$ & $13.0(8.1)$ & $10.7(6.7)$ & $10.3(7.7)$ & $43.6(20.1)$ & $65.6(25.7)$ \\
\hline
\end{tabular}


Table 3. Consumption characteristics and cooking methods of plantain-based products in Nigeria.

\begin{tabular}{|c|c|c|c|c|c|c|}
\hline Products & $\begin{array}{l}\text { Boiled Plantain } \\
(n=317)\end{array}$ & $\begin{array}{l}\text { Roasted Plantain } \\
(n=237)\end{array}$ & Fried as Chips $(n=274)$ & Fried as dodo $(n=406)$ & $\begin{array}{l}\text { Flour }^{2} \\
(n=164)\end{array}$ & $\begin{array}{l}\text { Pounded } \\
(n=89)\end{array}$ \\
\hline \multicolumn{7}{|l|}{ Consumption frequency (\%) } \\
\hline 1 time/day & 8.2 & 7.2 & 22.6 & 25.6 & 12.2 & 3.4 \\
\hline$>1$ time/day & 4.1 & 6.8 & 9.5 & 8.6 & 6.1 & 5.6 \\
\hline Weekly & 45.1 & 37.1 & 33.6 & 54.9 & 34.8 & 39.3 \\
\hline Monthly & 18.3 & 21.5 & 13.1 & 6.4 & 20.7 & 22.5 \\
\hline Occasionally & 24.3 & 27.4 & 21.2 & 4.4 & 26.2 & 29.2 \\
\hline \multicolumn{7}{|l|}{ Consumption trend till now (\%) } \\
\hline Constant & 24.8 & 24.2 & 23.3 & 17.7 & 23.8 & 27.3 \\
\hline Decreasing & 16.3 & 21.6 & 16.0 & 8.4 & 15.2 & 21.6 \\
\hline Finger size commonly used & Large & Small, Large & Small, Large & Large & Small, Large & Large \\
\hline \multicolumn{7}{|l|}{ Ripening stage (\%) } \\
\hline Matured green & 64.2 & 25.0 & 70.1 & 1.2 & 95.7 & 88.9 \\
\hline More yellow than green & 16.5 & 38.6 & 29.9 & 20.9 & 3.7 & 7.8 \\
\hline All yellow & 18.5 & 35.2 & 0.0 & 75.4 & 0.6 & 3.3 \\
\hline Yellow flecked with brown & 0.9 & 1.1 & 0.0 & 2.6 & 0.0 & 0.0 \\
\hline Common accompaniments & $\begin{array}{l}\text { Palm oil, stews, fish, } \\
\text { eggs, beans, rice, gari, } \\
\text { bread, vegetables }\end{array}$ & $\begin{array}{l}\text { Beans, groundnut, } \\
\text { palm oil, rice, }\end{array}$ & $\begin{array}{l}\text { Drinking water, soft } \\
\text { drinks }\end{array}$ & $\begin{array}{l}\text { Beans, rice, ugali, gari, } \\
\text { eggs, meat, stew }\end{array}$ & $\begin{array}{l}\text { Melon soup, vegetable } \\
\text { soup, yam, sweet potato, } \\
\text { boiled ripe plantain }\end{array}$ & $\begin{array}{l}\text { Melon soup, vegetable } \\
\text { soup, stew sauce, fish, } \\
\text { meats, ponmo (a meat } \\
\text { from the skin of cows, } \\
\text { goats, sheep, etc.) }\end{array}$ \\
\hline Cooking time $(\min )^{1}$ & $14.8(8.7)$ & $12.1(6.7)$ & $10.0(5.6)$ & $8.9(5.5)$ & $20.0(12.1)^{3}$ & $31.0(15.0)$ \\
\hline
\end{tabular}

${ }^{1}$ Value is the mean (standard deviation). ${ }^{2}$ Plantain flour is often mixed with cassava or yam flour before cooking. ${ }^{3}$ This cooking time means time for preparation of the plantain flour dishes. 
Interestingly, more than $20 \%$ of the respondents ate roasted, pounded, porridge, and flour products during occasions such as weddings and funerals. Roasted plantain is cooked on charcoal and often sold in the street with roasted fish or roasted African plum (Dacryodes edulis). Pounded plantain, in general, is prepared by boiling plantain for 30-45 min. The pulp is then pounded in a mortar and mixed with salt and other ingredients such as palm oil (Cameroon) or yam (Nigeria) until the paste becomes homogeneous. In some households, no ingredients are added to the pounded pulp. This pounded plantain can be eaten with various sauces, depending on culture and consumer preference. Dury et al. [20] stated that pounded plantain is not a common dish in cities, but is rather a favorite for the Beti people, a Southern ethnic group in Cameroon. To prepare porridge, plantain pulp is cut and boiled with water. Subsequently, salt, soy sauce (magi), pepper, palm oil, dried fish/meat, onion/tomato, etc., are added. The entire mixture is allowed to boil for about 30-70 min, depending on the cultivar and ripening stage of the plantain. In Cameroon, groundnut and meat might be added during boiling; therefore, no food accompaniments are required, while plantain porridge in Nigeria is frequently eaten with beans, vegetables, meat, and stews. However, Amah et al. [24] reported that porridge is more important in the South-South than in Nigeria's South-West.

In Nigeria, plantain chips are consumed as a snack, while some Cameroonians consume chips with other accompaniments such as beans, egg, fish, and meat. Plantain chips are prepared by frying slices of unripe or slightly ripe plantain pulp in vegetable oil for $10 \mathrm{~min}$ at a temperature of $160-180^{\circ} \mathrm{C}$. The production of plantain chips in Cameroon, Nigeria, and other African countries is principally a female activity. The consumption of plantain flour was only found in Nigeria. Honfo et al. [19] indicated that plantain flour is not incorporated in the food habit of Cameroonian people, except some from the North-West of the country. The same consumption trend of plantain flour was reported by Newilah Ngoh et al. [21]. To make plantain flour, unripe plantain is peeled and cut into small pieces before sun drying for 2-3 days. Subsequently, the dried pulp is ground in a wooden mortar or a maize grinder. A dish from plantain flour in Nigeria is prepared by mixing plantain flour with cassava or yam flour. Then water and ground ingredients of garlic, onion, groundnut oil, fish, and meat are added to the mixed flour; all ingredients are cooked for about $20 \mathrm{~min}$. Boiled plantain, yam, or sweet potato together with various soups appear to be the most common food complements for this dish.

The consumption of all plantain-based products over the last 5-10 years was constant in Cameroon $(\sim 40 \%)$, while the consumption increased in Nigeria $(>50 \%)$, particularly for dodo $(74 \%)$ (Tables 2 and 3). Both small and large plantain fingers were commonly used to prepare all these dishes; however, large fingers were preferred by Nigerian respondents for boiling, dodo, and pounded plantain. A finding of Ayinde et al. [38] supported that Nigerian consumers preferred plantain with medium or large fingers and with a shelf-life of 7-9 days under natural conditions. In contrast, Dury et al. [20] reported that Cameroonian women do not consider plantain a homogenous product, and usually, the preferred cultivar and size are different from one preparation to another. However, it should be noted that consumers and traders have their preferred trait preferences. For cooking bananas and plantains, consumer trait preferences are determined by the product type and processing method $[20,39,40]$. At the time of purchase, most consumers prefer fresh plantains with large bunches and large fruits. Kouamé et al. [37] found that for urban consumers in Côte d'Ivoire, plantain ripening/maturity stage used to prepare different foods was more important than other physical attributes. In contrast, traders only preferred plantains with large bunch sizes [41].

In Cameroon, unripe plantain was mostly used to make porridge (93\%), chips (56\%), and pounded plantain $(43 \%)$, while boiled $(47 \%)$ and roasted $(41 \%)$ plantain were often prepared by using ripe plantain with a peel more yellow than green (Tables 2 and 3). Ripe plantain with all-yellow peel (55\%) and overripe plantain (34\%) were used for frying as dodo. In contrast to Cameroonian dishes, unripe plantain (64\%) was used for boiling and overripe plantain (56\%) was used for making porridge in Nigeria. In addition, it was 
observed that Cameroonians and Nigerians use almost similar ingredients for cooking some common dishes such as boiled, roasted, and fried plantain. This assumes that people from the same culture or region have been affected in the same way culturally and therefore have similar food preferences, though it does not necessarily mean that foods need to be prepared in the same way or that they taste the same across geographical regions [42]. Another explanation of this behavior might be associated with the migration of plantain from Asia to Eastern Africa and then from Eastern Africa to Western Africa [43].

\subsection{Factors Influencing Consumer's Choice and Their Willingness to Purchase New Plantain-Based Products}

Taste was the most important factor affecting the choice in consuming fresh plantain $(66 \%)$ and their products $(81 \%)$ in Cameroon (Figure 3a1,b1), followed by availability ( $38 \%$ for fresh plantain and $34 \%$ for plantain-based products). On the other hand, nutrition (the biochemical and physiological process by which an organism uses food to support its life) was the most positively important factor influencing Nigerian consumer's choice in consuming fresh plantain $(69 \%)$ and their products $(68 \%)$, followed by taste $(59 \%$ for fresh plantain and $57 \%$ for plantain-based products (Figure 3a2,b2). Many studies agreed that taste and price have more of an influence on the food choice than a product's health benefits [44,45]. This result agreed with Kikulwe et al. [46], who reported that taste and price are the most important factors for purchasing cooking banana in Uganda. Sanya et al. [47] also documented that better consumption attributes such as taste, texture, and color could increase the likelihood of adopting improved banana hybrids by farmers in Uganda. Apart from taste, Ayinde et al. [38] observed that size and number of fingers were considered the most important factors when purchasing plantain, while appearance, color, and shelf-life were the least. Concerning taste, this finding was also in line with the choice of experiments of Hoek et al. [48], who found that when consumers find taste very important, they will not compromise and respond to price or other measures. A study of Amah et al. [24] found that most Nigerian respondents identified food quality characteristics related to color, texture, taste, and odor as the most important quality characteristics of plantain products.

In general, the presence of nutrition and health claims could negatively affect the expected tastiness of food products [49]. Verbeke [50] claimed that acceptance of foods with nutrition and health benefits has become more conditional, particularly for taste. Consumers have become more convinced that good taste and healthiness do not necessarily have to be traded off against each other. Hence, belief in the health benefits has become the strongest positive determinant of consuming foods with nutrition and health claims to such an extent that consumers are ready to compromise on taste. This reason may explain why nutrition was the most important factor for the Nigerian respondents in consuming plantains and their products. Many of them believe that the consumption of unripe plantain is good for health, especially in treating diarrhea [9]. Furthermore, Ayinde et al. [9] also revealed that the location of the respondents was an important factor in plantain consumption, as a higher percentage of urban Nigerian respondents was aware of the nutritional value of plantain, while most rural respondents were not aware. When the least important factors were considered, both Cameroonian and Nigerian respondents referred to packaging, location of produce, and size and quantity. Availability was not the most important factor, especially for the Nigerian respondents, La Trobe [51] indicated that consumers identified a lack of availability as their actual purchase barrier in purchasing locally produced goods.

In Cameroon and Nigeria, gender significantly influences $(p<0.05)$ taste, while education and annual income are associated with nutrition. In addition, household size is responsible for consumers' choices regarding the price of plantain products (Tables 4 and 5). Regarding the effect of gender, Amah et al. [24] reported that men primarily focus on the yield of plantain production. At the same time, women might have spread their preferences more over the other characteristics that are related to home consumption. This could be used to explain women's dominance in plantain food product processing, involving more hands-on interaction with the quality-related aspects of the plantain. This observation also 
depicted that education is an important factor in increasing awareness and obtaining more information and knowledge about high-quality products. Dhamotharan and Selvaraj [52] found that the better product knowledge of highly educated consumers helps them to seek more information about labels and brands to buy quality geographical indication (GI) registered bananas. They suggested that emphasizing the importance of promoting these specific products through print and mass media by providing the information on health benefits in terms of medicinal and nutritive value could increase willingness to pay in literate consumers. Moreover, Ayinde et al. [9] displayed that consumption of plantain is determined by occupation. Their results showed that teachers with higher education consumed more plantain because of their awareness of its nutritional value. However, Garnett et al. [53] highlighted that education on healthy and sustainable food products does not necessarily shift consumer responsiveness to healthier and more sustainable foods. Hence, it is important to consider the interaction between consumers and products at the research level, and then different points of purchase should be discussed at the food policy and marketing levels.

(a1)

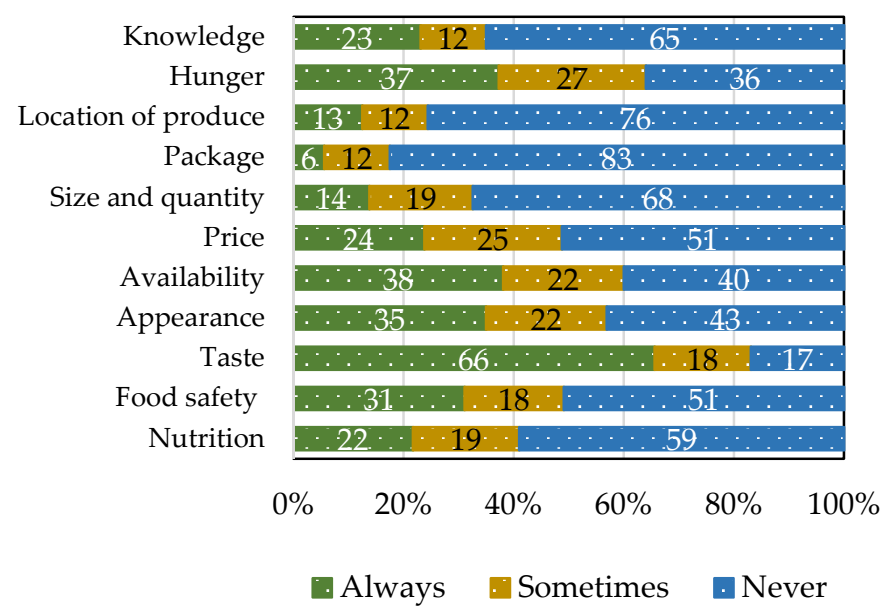

(b1)

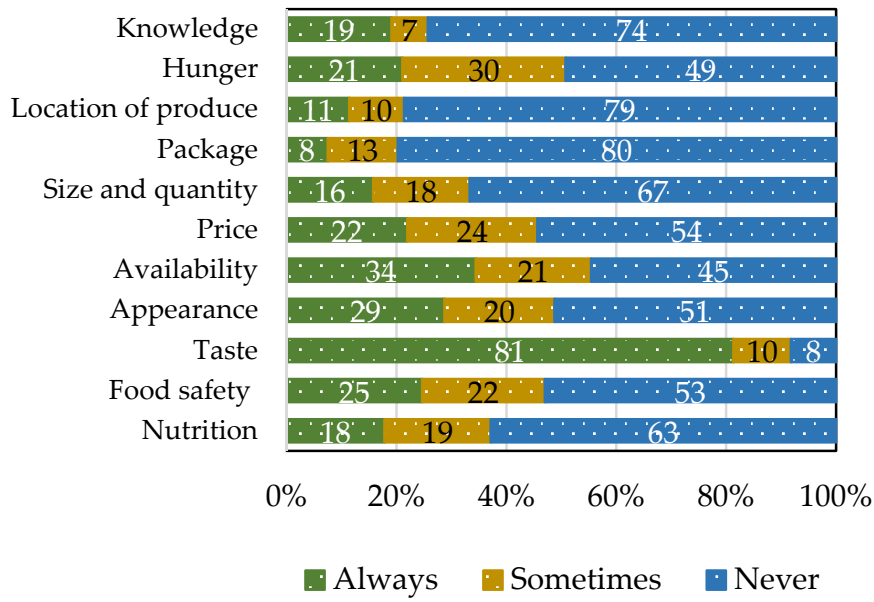

(a2)

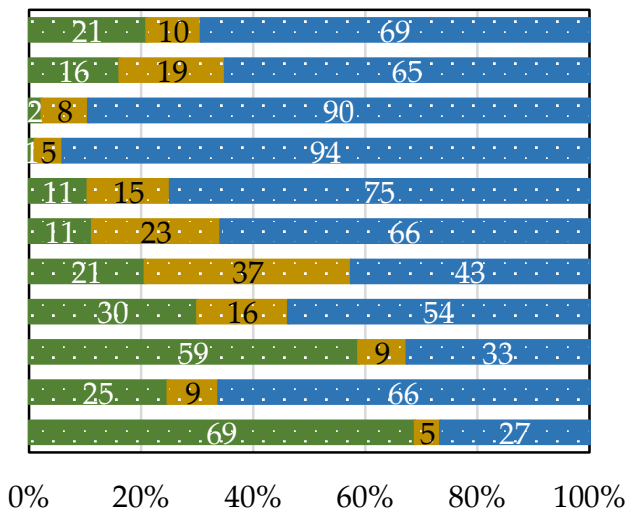

(b2)

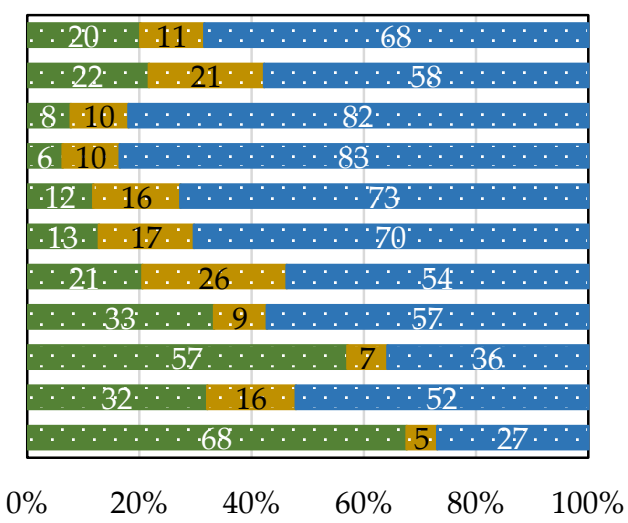

Figure 3. Factors influencing consumer choice for consuming fresh plantain (a) and their products ${ }^{1}$ (b) in Cameroon (1) and Nigeria (2). ${ }^{1}$ An average value of all plantain-based products including boiled, roast, chips, dodo, flour, pounded, and porridge; however, flour was excluded from plantain-based products in Cameroon due to unavailability. 
Table 4. Factors determining consumer's choices for consumption of plantain-based products in Cameroon.

\begin{tabular}{|c|c|c|c|c|c|}
\hline \multirow{2}{*}{ Product Factors } & \multicolumn{5}{|l|}{ Cameroon } \\
\hline & Sex & Age & Education & Household Size & Annual Income ${ }^{1}$ \\
\hline \multicolumn{6}{|l|}{ Nutrition } \\
\hline Always & $0.42(0.48)$ & $40.51(14.20)$ & $10.51(3.02)$ & $5.51(1.24)$ & $0.75(0.22)$ \\
\hline Sometimes & $0.44(0.49)$ & 40.30 (12.18) & $8.12(2.04)$ & $6.03(1.02)$ & $0.67(0.23)$ \\
\hline Never & $0.45(0.50)$ & 39.23 (14.41) & $7.25(2.31)$ & $5.67(0.98)$ & $0.48(0.12)$ \\
\hline F-test & 0.58 & 1.52 & $1.91 *$ & 0.45 & $1.13^{*}$ \\
\hline \multicolumn{6}{|l|}{ Food safety } \\
\hline Always & $0.46(0.47)$ & $44.71(12.72)$ & $11.12(2.15)$ & $5.08(1.02)$ & $0.65(0.18)$ \\
\hline Sometimes & $0.42(0.49)$ & 40.85 (10.50) & $10.56(1.57)$ & $5.25(2.21)$ & $0.62(0.32)$ \\
\hline Never & $0.42(0.50)$ & 41.72 (12.33) & $12.15(3.01)$ & $5.43(1.17)$ & $0.58(0.21)$ \\
\hline F-test & 1.01 & 0.47 & 0.08 & 0.95 & 0.82 \\
\hline \multicolumn{6}{|l|}{ Taste } \\
\hline Always & $0.48(0.49)$ & 40.24 (12.13) & $9.56(1.82)$ & $6.12(2.03)$ & $0.45(0.18)$ \\
\hline Sometimes & $0.37(0.42)$ & 41.15 (12.82) & $10.03(2.03)$ & 7.14 (1.98) & $0.53(0.20)$ \\
\hline Never & $0.32(0.45)$ & 40.72 (13.50) & $9.82(1.14)$ & $6.57(2.36)$ & $0.47(0.34)$ \\
\hline F-test & $1.52 * *$ & 0.05 & 0.70 & 1.06 & 0.81 \\
\hline \multicolumn{6}{|l|}{ Appearance } \\
\hline Always & $0.47(0.50)$ & $39.87(12.40)$ & $10.25(2.03)$ & $7.28(2.11)$ & $0.52(0.35)$ \\
\hline Sometimes & $0.39(0.47)$ & 38.54 (11.35) & $9.88(1.95)$ & $7.54(2.31)$ & $0.45(0.51)$ \\
\hline Never & $0.42(0.49)$ & $39.23(10.24)$ & $10.04(2.56)$ & $7.08(2.12)$ & $0.48(0.36)$ \\
\hline F-test & 0.98 & 0.53 & 0.90 & 1.00 & 0.07 \\
\hline \multicolumn{6}{|l|}{ Availability } \\
\hline Always & $0.41(0.50)$ & $40.17(11.82)$ & $11.11(4.05)$ & $6.02(2.04)$ & $0.45(0.32)$ \\
\hline Sometimes & $0.43(0.49)$ & 39.91 (13.15) & $10.58(2.03)$ & $5.78(2.13)$ & $0.37(0.30)$ \\
\hline Never & $0.45(0.49)$ & $39.43(12.37)$ & $11.02(2.12)$ & $6.74(3.01)$ & $0.46(0.27)$ \\
\hline F-test & 0.68 & 0.87 & 0.96 & 0.75 & 0.69 \\
\hline \multicolumn{6}{|l|}{ Price } \\
\hline Always & $0.43(0.49)$ & $38.80(10.84)$ & $10.12(2.54)$ & $7.21(1.15)$ & $0.52(0.34)$ \\
\hline Sometimes & $0.42(0.48)$ & $37.51(12.31)$ & $9.86(3.02)$ & $5.23(1.09)$ & $0.21(0.18)$ \\
\hline Never & $0.45(0.51)$ & 39.23 (11.57) & $9.44(2.25)$ & $4.78(2.05)$ & $0.38(0.41)$ \\
\hline F-test & 0.97 & 0.00 & 0.70 & $1.35^{*}$ & 1.07 \\
\hline \multicolumn{6}{|l|}{ Size and quantity } \\
\hline Always & $0.45(0.50)$ & 39.62 (13.03) & $10.23(2.57)$ & $6.78(2.31)$ & $0.46(0.35)$ \\
\hline Sometimes & $0.47(0.49)$ & 40.43 (12.46) & $11.01(2.18)$ & $5.22(1.09)$ & $0.50(0.29)$ \\
\hline Never & $0.44(0.50)$ & 41.28 (13.25) & $11.14(2.21)$ & $5.01(1.23)$ & $0.42(0.41)$ \\
\hline F-test & 1.10 & 0.72 & 0.51 & 0.64 & 0.41 \\
\hline \multicolumn{6}{|l|}{ Package } \\
\hline Always & $0.41(0.49)$ & $38.83(12.05)$ & $9.87(1.89)$ & $6.57(2.15)$ & $0.44(0.32)$ \\
\hline Sometimes & $0.39(0.50)$ & $39.22(9.18)$ & $10.23(2.11)$ & $7.02(1.89)$ & $0.37(0.13)$ \\
\hline Never & $0.38(0.48)$ & 40.17 (10.56) & $10.57(2.78)$ & $6.98(3.01)$ & $0.46(0.35)$ \\
\hline F-test & 0.78 & 0.64 & 0.86 & 0.53 & 0.51 \\
\hline \multicolumn{6}{|c|}{ Location of produce } \\
\hline Always & $0.38(0.49)$ & $42.24(11.05)$ & $11.21(1.85)$ & $7.18(2.57)$ & $0.52(0.23)$ \\
\hline Sometimes & $0.37(0.48)$ & $41.18(12.10)$ & $10.57(2.22)$ & $7.01(1.45)$ & $0.48(0.31)$ \\
\hline Never & $0.35(0.49)$ & 43.02 (11.23) & $11.48(2.09)$ & $6.74(2.08)$ & $0.51(0.43)$ \\
\hline F-test & 0.98 & 0.48 & 1.01 & 1.06 & 0.15 \\
\hline \multicolumn{6}{|l|}{ Hunger } \\
\hline Always & $0.47(0.49)$ & $38.72(9.82)$ & $12.12(3.02)$ & $6.47(1.75)$ & $0.47(0.34)$ \\
\hline Sometimes & $0.38(0.49)$ & 39.13 (12.03) & $12.25(1.92)$ & $6.38(2.21)$ & $0.41(0.28)$ \\
\hline Never & $0.43(0.50)$ & $39.46(10.54)$ & $11.89(2.04)$ & $6.69(2.05)$ & $0.50(0.43)$ \\
\hline F-test & 0.56 & 0.84 & 0.84 & 0.70 & 1.02 \\
\hline \multicolumn{6}{|l|}{ Knowledge } \\
\hline Always & $0.45(0.49)$ & 45.75 (12.19) & $12.08(2.15)$ & $6.89(3.00)$ & $0.41(0.35)$ \\
\hline Sometimes & $0.47(0.50)$ & 40.68 (11.14) & $11.57(2.32)$ & $7.18(2.15)$ & $0.58(0.44)$ \\
\hline Never & $0.43(0.48)$ & $41.36(9.96)$ & $11.43(3.11)$ & $6.47(2.11)$ & $0.52(0.32)$ \\
\hline F-test & 1.12 & 0.92 & 0.61 & 1.37 & 0.73 \\
\hline
\end{tabular}

Standard deviations are in parentheses. ${ }^{*}, * *$ indicate significant differences at levels of $5 \%$ and $1 \%$, respectively. ${ }^{1} 1$ if $<$ USD 1800 , otherwise 0 . 
Table 5. Factors determining consumers' choices for consumption of plantain-based products in Nigeria.

\begin{tabular}{|c|c|c|c|c|c|}
\hline \multirow{2}{*}{ Product Factors } & \multicolumn{5}{|l|}{ Nigeria } \\
\hline & Sex & Age & Education & Household Size & Annual Income ${ }^{1}$ \\
\hline \multicolumn{6}{|l|}{ Nutrition } \\
\hline Always & $0.48(0.48)$ & $40.23(13.18)$ & $13.57(4.12)$ & $5.09(1.18)$ & $0.55(0.49)$ \\
\hline Sometimes & $0.42(0.49)$ & $44.04(12.56)$ & $10.08(3.51)$ & $4.57(0.95)$ & $0.31(0.45)$ \\
\hline Never & $0.44(0.50)$ & 43.10 (11.64) & $8.14(3.23)$ & $4.98(2.01)$ & $0.24(0.37)$ \\
\hline F-test & 0.62 & 1.72 & $1.98^{* *}$ & 0.52 & $1.08 *$ \\
\hline \multicolumn{6}{|l|}{ Food safety } \\
\hline Always & $0.45(0.49)$ & 43.54 (11.98) & $12.08(3.07)$ & $4.78(2.14)$ & $0.48(0.23)$ \\
\hline Sometimes & $0.47(0.50)$ & $44.15(12.03)$ & $12.56(2.34)$ & $4.52(1.55)$ & $0.42(0.41)$ \\
\hline Never & $0.41(0.48)$ & 42.08 (13.11) & $10.78(2.75)$ & $4.39(1.72)$ & $0.40(0.43)$ \\
\hline F-test & 1.28 & 0.56 & 0.15 & 1.05 & 0.67 \\
\hline \multicolumn{6}{|l|}{ Taste } \\
\hline Always & $0.45(0.49)$ & $45.75(13.02)$ & $11.16(2.56)$ & $5.71(1.87)$ & $0.56(0.48)$ \\
\hline Sometimes & $0.35(0.50)$ & 44.38 (14.15) & $12.23(3.12)$ & $5.14(2.02)$ & $0.48(0.50)$ \\
\hline Never & $0.30(0.48)$ & 45.69 (13.78) & $13.02(2.45)$ & $5.49(1.28)$ & $0.52(0.44)$ \\
\hline F-test & $1.44^{*}$ & 0.10 & 0.87 & 0.98 & 0.92 \\
\hline \multicolumn{6}{|l|}{ Appearance } \\
\hline Always & $0.42(0.50)$ & $41.25(14.49)$ & $12.14(2.76)$ & $6.01(2.08)$ & $0.47(0.40)$ \\
\hline Sometimes & $0.43(0.50)$ & 41.36 (15.14) & $11.47(2.85)$ & $5.78(1.98)$ & $0.42(0.48)$ \\
\hline Never & $0.44(0.49)$ & $40.68(12.86)$ & $11.87(3.03)$ & $6.13(2.32)$ & $0.45(0.39)$ \\
\hline F-test & 1.08 & 0.44 & 0.97 & 0.87 & 0.11 \\
\hline \multicolumn{6}{|l|}{ Availability } \\
\hline Always & $0.43(0.48)$ & $41.23(12.05)$ & $13.42(5.02)$ & $4.87(1.95)$ & $0.38(0.35)$ \\
\hline Sometimes & $0.44(0.50)$ & 42.18 (11.57) & $12.28(3.12)$ & $5.13(2.04)$ & $0.40(0.41)$ \\
\hline Never & $0.40(0.49)$ & 41.84 (13.08) & $12.51(2.87)$ & $4.58(2.29)$ & $0.39(0.48)$ \\
\hline F-test & 0.51 & 0.95 & 1.03 & 0.87 & 0.78 \\
\hline \multicolumn{6}{|l|}{ Price } \\
\hline Always & $0.40(0.49)$ & $39.67(11.45)$ & $12.03(2.05)$ & $6.28(1.19)$ & $0.54(0.52)$ \\
\hline Sometimes & $0.40(0.50)$ & 40.08 (12.08) & $12.28(3.24)$ & $5.02(2.01)$ & $0.42(0.29)$ \\
\hline Never & $0.44(0.45)$ & $41.13(10.92)$ & $13.04(3.09)$ & $4.19(1.28)$ & $0.50(0.32)$ \\
\hline F-test & 1.03 & 0.05 & 0.67 & $1.47^{*}$ & 1.11 \\
\hline \multicolumn{6}{|l|}{ Size and quantity } \\
\hline Always & $0.41(0.50)$ & $44.08(12.15)$ & $12.08(3.26)$ & $4.98(1.75)$ & $0.52(0.50)$ \\
\hline Sometimes & $0.43(0.49)$ & 42.15 (13.11) & $13.19(2.54)$ & $5.26(2.02)$ & $0.55(0.41)$ \\
\hline Never & $0.45(0.50)$ & $43.16(10.75)$ & $12.59(2.78)$ & $5.14(1.92)$ & $0.48(0.28)$ \\
\hline F-test & 0.89 & 0.58 & 0.63 & 0.60 & 0.37 \\
\hline \multicolumn{6}{|l|}{ Package } \\
\hline Always & $0.35(0.50)$ & $41.68(12.65)$ & $11.25(2.43)$ & $5.28(2.04)$ & $0.53(0.47)$ \\
\hline Sometimes & $0.32(0.50)$ & 40.15 (10.08) & $12.09(3.16)$ & $5.02(2.22)$ & $0.48(0.50)$ \\
\hline Never & $0.37(0.48)$ & $39.48(12.13)$ & $12.72(2.49)$ & $6.13(1.75)$ & $0.50(0.42)$ \\
\hline F-test & 0.84 & 0.86 & 0.65 & 0.57 & 0.64 \\
\hline \multicolumn{6}{|c|}{ Location of produce } \\
\hline Always & $0.40(0.49)$ & $44.25(9.87)$ & $12.09(3.51)$ & $5.45(1.67)$ & $0.35(0.32)$ \\
\hline Sometimes & $0.37(0.50)$ & 46.12 (11.68) & $13.61(2.52)$ & $5.87(2.11)$ & $0.43(0.41)$ \\
\hline Never & $0.39(0.50)$ & $43.08(10.56)$ & $12.58(2.71)$ & $5.13(1.89)$ & $0.39(0.47)$ \\
\hline F-test & 1.15 & 0.55 & 1.20 & 1.14 & 0.09 \\
\hline \multicolumn{6}{|l|}{ Hunger } \\
\hline Always & $0.42(0.50)$ & $45.05(12.11)$ & $14.03(1.45)$ & $5.08(2.03)$ & $0.42(0.42)$ \\
\hline Sometimes & $0.40(0.49)$ & 44.21 (11.45) & $14.11(2.05)$ & $4.89(1.14)$ & $0.50(0.35)$ \\
\hline Never & $0.39(0.48)$ & 42.09 (13.01) & $13.87(2.44)$ & $5.12(1.97)$ & $0.44(0.47)$ \\
\hline F-test & 0.45 & 0.76 & 0.92 & 0.56 & 0.98 \\
\hline \multicolumn{6}{|l|}{ Knowledge } \\
\hline Always & $0.37(0.50)$ & $46.12(10.56)$ & $13.42(3.45)$ & $5.87(2.05)$ & $0.51(0.40)$ \\
\hline Sometimes & $0.32(0.50)$ & 44.08 (12.08) & $12.57(2.87)$ & $5.13(2.23)$ & $0.50(0.44)$ \\
\hline Never & $0.35(0.49)$ & 45.04 (10.76) & $14.23(2.98)$ & $5.46(1.74)$ & $0.55(0.39)$ \\
\hline F-test & 1.28 & 0.83 & 0.75 & 1.51 & 0.82 \\
\hline
\end{tabular}

Standard deviations are in parentheses. ${ }^{*},{ }^{* *}$ indicate significant differences at levels of $5 \%$ and $1 \%$, respectively. ${ }^{1} 1$ if < USD 1800 , otherwise 0 .

A higher income allows better access and higher-quality food. Dury et al. [20] showed that although plantain is the preferred staple for most households, family income may 
constrain its consumption. A study by Kikulwe et al. [46] also reported that the Ugandan respondents with higher incomes were more likely to purchase GM bananas with improved nutrition and taste. Likewise, Jolly et al. [54] and Sabran et al. [55] stated that the wealthier are more likely to take precautions about food and are more willing to pay for high-quality products than those with lower incomes. Additionally, Silva [56] found that food-secure households with higher incomes purchased a wider variety of high-quality food items compared to food-insecure households with lower incomes. Smaller households were more likely to pay than those with a larger household size. Again, Kikulwe et al. [46] showed that larger household sizes were associated with fewer purchases of GM bananas. This also implies that larger households, especially in lower-income communities, can choose to consume only low-priced goods of lower quality. Basan [57] proposed that consumers in different income classes in the society could have their preferences when making purchase decisions concerning the embodied attributes of bananas. Therefore, a well-informed clientele can be selected, and a proper market segmentation and marketing plan can be prepared to increase the profit of farmers and traders.

Moreover, about $78 \%$ of Cameroonian and $95 \%$ of Nigerian respondents purchased plantain-based products from the market (Table 6). Although more than $70 \%$ of them were very satisfied with those plantain products, almost $100 \%$ were willing to pay slightly more for new plantain products if their quality can significantly improve their health. This result is consistent with Kim and Chung [58], who showed that health has a significant effect on consumers' attitudes. However, Lange et al. [59] reported that consumers might indicate a strong preference or purchase intent for a product perceived as high quality without buying it when in a purchasing situation. Therefore, a more realistic assessment of price relative to other product attributes apart from health should also be considered through a conjoint study or experimental auction [30].

Table 6. Respondents' satisfaction and attitude responsible for plantain products.

\begin{tabular}{|c|c|c|c|c|c|}
\hline \multirow{2}{*}{ No. } & \multirow{2}{*}{ Statements } & \multicolumn{2}{|c|}{ Response (\%) } & \multirow{2}{*}{ Chi-Square Value } & \multirow{2}{*}{$p$ Value } \\
\hline & & Cameroon & Nigeria & & \\
\hline 1 & I have purchased plantain products from the market. & 78.5 & 94.5 & 4.59 & 0.01 \\
\hline 2 & $\begin{array}{l}\text { I am very satisfied with those plantain products from } \\
\text { the market. }\end{array}$ & 70.1 & 87.6 & 3.25 & 0.04 \\
\hline 3 & $\begin{array}{l}\text { I would like to pay slightly more for new plantain products if } \\
\text { their quality can improve my health. }\end{array}$ & 99.3 & 98.1 & 3.02 & 0.38 \\
\hline 4 & I would buy new plantain products if they are more delicious. & 76.2 & 66.2 & 5.14 & 0.12 \\
\hline 5 & I would buy new plantain products if they are more nutritious. & 61.9 & 78.5 & 6.13 & 0.05 \\
\hline 6 & I would buy new plantain products if there is a greater quantity. & 30.2 & 25.0 & 6.78 & 0.21 \\
\hline 7 & I would buy new plantain products if they have a lower price. & 47.6 & 44.6 & 5.45 & 0.28 \\
\hline 8 & $\begin{array}{l}\text { I would buy new plantain products if they are available in } \\
\text { the market. }\end{array}$ & 54.3 & 52.2 & 7.52 & 0.32 \\
\hline
\end{tabular}

When the respondents were asked to indicate their attitude toward buying new plantain-based products if they were: (1) more delicious; (2) more nutritious; (3) greater quantity; (4) lower price; and (5) more available in the markets, Cameroonian respondents were willing to pay more if the new plantain products were tastier than the existing products, while new products with improved nutrition are highly targeted for Nigerian respondents. Quantity of products was considered the least when compared to other product factors. Bruschi et al. [60] stated that the willingness to pay for intrinsic attributes such as taste and nutrition also depends on other factors such as cultural and sociodemographic/economic characteristics and type of product. This agrees with Wang et al. [61], who confirmed that health concerns regarding the consumption of nutritious foods in China and Europe might be different due to dietary patterns, culture, and customs. While Köster [62] explained sensory preferences, particularly taste, as unconscious and unintentional learning processes, those established in childhood are important in predicting 
preferences later in life. Although the Nigerian respondents considered nutrition the most important factor influencing their choice of consumption or willingness to pay for plantain products, this can be both true or false, because most of them had little understanding of the actual nutritional value of plantain. When asked to name the important nutrients in plantain, "protein" was their first answer, or to list what kind of new plantain products they want in the markets, about $15 \%$ of the respondents listed plantain oil, products rich in protein, etc. This finding underlined that increasing consumers' knowledge of the actual health benefits of plantain through nutrition education and training and/or spoken media is very crucial, as it might result in creating greater awareness and increasing more consumption and utilization of plantain. Zepada and Dela [63] illustrated that increasing and deepening knowledge can reinforce existing values of products, which then influence beliefs and norms, leading to sustainable food purchase behavior. In addition, Klopčič et al. [45] suggested that the functions/benefits of the nutrients need to be expressed in clear, direct, short, and simple language without using scientific terms. A symbol on a package can affect consumers' product evaluations and stimulate purchasing [64], especially by those such as the Cameroonian respondents, who are less motivated by health.

\section{Conclusions}

This study examined consumption characteristics, cooking methods, and preferences of plantain and its products among consumers in the Central Region of Cameroon and Oyo State of Nigeria. Taste was the most critical factor for consuming plantains and their products for Cameroonian respondents, while Nigerian respondents valued their nutrition. In addition, this study clearly indicated the similarities and differences in consumption characteristics and cooking methods of plantain food products in those study areas, which can principally be explained by ethnic traditions and plantain migrations. The results also suggested that gender played a prominent role in consumers' choice in consuming plantain-based products, while education and annual income had a significant influence on the selection of products with nutritional traits. Household size tended to be taken into consideration when the price is associated. Although a larger proportion of respondents probably buy or do not buy a certain product, it does not mean they would not buy it, especially if the new product appears on the market with distinguishing characteristics. These points are very important even if consumers are not demanding improved varieties of plantains. Breeders still need to be aware of critical end-user traits, as they provide very useful information to help plantain breeding teams to adapt to and revisit the product profiles and breeding priorities. For the food-processing sector, the physiological stages of harvesting and postharvest treatment processes should be focused on a better understanding of the dynamics of useful compounds. Investigating the various factors of plantain composition, and the interactions between the various constituents, will be a source of knowledge for the choice and control of processing operations. Moreover, innovative approaches in plantain processing; for example, using hybrid solar dryers to make high-quality plantain flour, can be applied to meet consumer demand. Finally, there is a need to create awareness of the importance of plantain with regard to its nutritional significance.

Author Contributions: Conceptualization, P.U. and C.M.; methodology, P.U. and C.M.; validation, B.I.; formal analysis, P.U.; investigation, R.S.; writing-original draft preparation, P.U.; writingreview and editing, C.M., R.S., B.I., A.F.K., A.A., J.L., D.O.I. and B.V. All authors have read and agreed to the published version of the manuscript.

Funding: This work was carried out with financial support from the African Union Research Grants, Reference: HRST/ST/AURG-II/CALL2/2018, to the International Institute of Tropical Agriculture via a project entitled "Enhancing nutritional quality of plantain food products through improved access to endophyte primed and high provitamin A plantain cultivars under integrated soil fertility management practices in Nigeria, Cameroon, and Gabon".

Institutional Review Board Statement: Not applicable.

Informed Consent Statement: Not applicable. 
Data Availability Statement: This manuscript has no associated data.

Acknowledgments: The authors are grateful to Olaide Aderibigbe (NIHORT, Nigeria) and Rebecca Ibe (NIHORT, Nigeria) for their technical support. The authors also thank all donors who supported this work through their contributions to the CGIAR Fund (http:/ / www.cgiar.org/funders (accessed on 10 August 2021)), and in particular to the CGIAR Research Program on Roots, Tubers, and Bananas (RTB-CRP).

Conflicts of Interest: The authors declare no conflict of interest.

\section{References}

1. Adepoju, O.T.; Sunday, B.E.; Folaranmi, O.A. Nutrient composition and contribution of plantain (Musa paradisiaca) products to dietary diversity of Nigerian consumers. Afr. J. Biotechnol 2012, 11, 13601-13605. [CrossRef]

2. Ekesa, B.; Nabuuma, D.; Blomme, G.; Van den Bergh, I. Provitamin A carotenoid content of unripe and ripe banana cultivars for potential adoption in eastern Africa. J. Food Compost. Anal. 2015, 43, 1-6. [CrossRef]

3. Passo Tsamo, C.V.; Herent, M.F.; Tomekpe, K.; Emaga, T.H.; Quetin-Leclercq, J.; Rogez, H.; Larondelle, Y.; Andre, C. Phenolic profiling in the pulp and peel of nine plantain cultivars (Musa sp.). Food Chem. 2015, 167, 197-204. [CrossRef]

4. Anyasi, T.A.; Jideani, A.I.O.; McHau, G.R.A. Phenolics and essential mineral profile of organic acid pretreated unripe banana flour. Food Res. Int. 2018, 104, 100-109. [CrossRef] [PubMed]

5. Sidhu, J.S.; Zafar, T.A. Bioactive compounds in banana fruits and their health benefits. Food Qual. Saf. 2018, 2, 183-188. [CrossRef]

6. Amah, D.; van Biljon, A.; Brown, A.; Perkins-Veazie, P.; Swennen, R.; Labuschagne, M. Recent advances in banana (Musa spp.) biofortification to alleviate vitamin A deficiency. Crit. Rev. Food Sci. Nutr. 2019, 59, 3498-3510. [CrossRef]

7. Egbebi, A.O.; Bademosi, T.A. Chemical composition of ripe and unripe banana and plantain. Int. J. Trop. Med. Public Health 2011, $3,18-22$.

8. Adegunwa, M.O.; Oloyede, I.O.; Adebanjo, L.A.; Alamu, E.O. Quality attribute of plantain (Musa paradisiaca) sponge-cake supplemented with watermelon (Citrullus lanatus) rind flour. Cogent Food Agric. 2019, 5, 1631582. [CrossRef]

9. Ayinde, O.E.; Daramola, C.O.; Animashaun, J.O.; Oloyede, W.O. Consumption and expenditure patterns of plantain-based foods in rural and urban areas in Kware State, Nigeria. J. Multidiscip. Stud. 2017, 6, 1-16.

10. Naczk, M.; Shahidi, F. Phenolics in cereals, fruits and vegetables: Occurrence, extraction and analysis. J. Pharm. Biomed. Anal. 2006, 41, 1523-1542. [CrossRef]

11. Bennett, R.N.; Shiga, T.M.; Hassimotto, N.M.A.; Rosa, E.A.S.; Lajolo, F.M.; Cordenunsi, B.R. Phenolics and antioxidant properties of fruit pulp and cell wall fractions of postharvest banana (Musa acuminata Juss.) cultivars. J. Agric. Food Chem. 2010, 58, 7991-8003. [CrossRef]

12. Pereira, A.; Maraschin, M. Banana (Musa spp.) from peel to pulp: Ethnopharmacology, source of bioactive compounds and its relevance for human health. J. Ethnopharmacol. 2015, 160, 149-163. [CrossRef]

13. Tomekpe, K.; Kwa, M.; Dzomeku, B.M.; Ganry, J. CARBAP and innovation on the plantain banana in Western and Central Africa. Int. J. Agric. Sustain. 2011, 9, 264-273. [CrossRef]

14. Amankwah, E.A.; Ayim, I.; Dzisi, K.A.; Barimah, J. Nutritional content and functional properties of French Horn, False Horn and FHIA-21. Am. J. Food Technol. 2011, 6, 322-328. [CrossRef]

15. Marriott, J.; Lancaster, E.A. Bananas and Plantains. In Handbook of Tropical Foods; Chan, J.H.T., Ed.; Marcel Dekker Inc.: New York, NY, USA, 1983; pp. 85-145.

16. FAOSTAT. 2021. Available online: http://www.fao.org/faostat/en/\#data/BC (accessed on 14 August 2021).

17. Adi, D.D.; Oduro, I.N.; Tortoe, C. Physicochemical changes in plantain during normal storage ripening. Sci. Afr. 2019, 6, e00164. [CrossRef]

18. Happi Emaga, T.; Wathelet, B.; Paquot, M. Changements texturaux et biochimiques des fruits du bananier au cours de la maturation. Leur influence sur la préservation de la qualité du fruit et la maîtrise de la maturation. Biotechnol. Agron. Soc. Environ. 2008, 12, 89-98.

19. Honfo, F.G.; Tenkouano, A.; Coulibaly, O. Banana and plantain-based foods consumption by children and mothers in Cameroon and Southern Nigeria: A comparative study. Afr. J. Food Sci. 2011, 5, 287-291.

20. Dury, S.; Bricas, N.; Tchango-Tchango, J.; Temple, L.; Bikoi, A. The determinants of urban plantain consumption in Cameroon. Food Qual. Prefer. 2002, 13, 81-88. [CrossRef]

21. Ngoh Newilah, G.; Tchango-Tchango, J.; Fokou, E.; Etoa, F.X. Processing and food uses of banana and plantains in Cameroon. Fruits 2005, 60, 245-253. [CrossRef]

22. Okolle, J.N.; Fansi, G.H.; Lombi, F.M.; Lang, P.S.; Loubana, P.M. Banana entomological reserach in Cameroon: How far and what next? Afr. J. Plant. Sci. Biotechnol. 2009, 3, 1-19.

23. Oktay, S.; Sadikoğlu, S. The gastronomic cultures' impact on the African cuisine. J. Ethn. Foods 2018, 5, 140-146. [CrossRef]

24. Amah, D.; Stuart, E.; Mignouna, D.; Swennen, R.; Teeken, B. End-user preferences for plantain food products in Nigeria and implications for genetic improvement. Int. J. Food Sci. Technol. 2020. [CrossRef]

25. Adeoye, I.B.; Oni, O.A. Policy analysis and competitiveness of plantain processing in Southwestern Nigeria. J. Sustain. Dev. Afr. 2013, 15, 135-151. 
26. Horvat, A.; Granato, G.; Fogliano, V.; Luning, P.A. Understanding consumer data use in new product development and the product life cycle in European food firms-An empirical study. Food Qual. Prefer. 2019, 76, 20-32. [CrossRef]

27. Otto, K.N.; Wood, K.L. Product Design: Techniques in Reverse Engineering and New Product Development; Pearson Education Asia Limited: Beijing, China; Tsinghua University Press: Beijing, China, 2003.

28. Van Kleef, E.; van Trijp, H.C.M.; Luning, P. Functional foods: Health claim, food product compatibility, and the impact of health claim framing on consumer evaluation. Appetite 2005, 44, 299-308. [CrossRef] [PubMed]

29. Siró, I.; Kápolna, E.; Kápolna, B.; Lugasi, A. Functional food. Product development, marketing and consumer acceptance-A review. Appetite 2008, 51, 456-467. [CrossRef]

30. Symmank, C.; Zahn, S.; Rohm, H. Visually suboptimal bananas: How ripeness affects consumer expectation and perception. Appetite 2018, 120, 472-481. [CrossRef]

31. Li, X.E.; Jervis, S.M.; Drake, M.A. Examining extrinsic factors that influence product acceptance: A review. J. Food Sci. 2015, 80, R901-R909. [CrossRef]

32. De Pelsmaeker, S.; Gellynck, X.; Delbaere, C.; Declercq, N.; Dewettinck, K. Consumer-driven product development and improvement combined with sensory analysis: A case-study for European filled chocolates. Food Qual. Prefer. 2015, 41, 20-29. [CrossRef]

33. De Pelsmaeker, S.; Schouteten, J.; Lagast, S.; Dewettinck, K.; Gellynck, X. Is taste the key driver for consumer preference? A conjoint analysis study. Food Qual. Prefer. 2017, 62, 323-331. [CrossRef]

34. Solheim, R.; Lawless, H.T. Consumer purchase probability affected by attitude towards low-fat foods, liking, private body consciousness and information on fat and price. Food Qual. Prefer. 1996, 7, 137-143. [CrossRef]

35. Chamorro, A.; Rubio, S.; Miranda, F.J. The region-of-origin (ROO) effect on purchasing preferences. Bri. Food J. 2015, 117, 820-839. [CrossRef]

36. Hällsten, M.; Edling, C.; Rydgren, J. Social capital, friendship networks, and youth unemployment. Soc. Sci. Res. 2016, 61, 234-250. [CrossRef]

37. Kouamé, C.A.; Kouassi, N.K.; N'dri, D.Y.; Amani, G.N.G. Plantain (Musa spp., AAB genome) cultivar preference, local processing techniques and consumption patterns of plantain-based foods mostly consumed in urban area of Abidjan, Côte d'Ivoire. Nat. Technol. 2015, 12, 115.

38. Ayinde, O.E.; Adewumi, M.O.; Folorunsho, W.O. Consumer preference of banana (Musa spp.) in Kwara state, Nigeria. Acta Hortic. 2010, 879, 89-93. [CrossRef]

39. Dzomeku, B.M.; Osei-Owusu, M.; Ankomah, A.A.; Akyeampong, E.; Darkey, S.K. Sensory evaluation of some cooking bananas in Ghana. J. Appl. Sci. 2006, 6, 835-837. [CrossRef]

40. Dzomeku, B.M.; Armo-Annor, F.; Adjei-Gyan, K.; Ansah, J.; Nkakwa, A.; Darkey, S.K. On-farm evaluation and consumer acceptability study of selected tetraploid Musa hybrid in Ghana. J. Plant. Sci. 2008, 3, 216-223. [CrossRef]

41. Marimo, P.; Caron, C.; Van Den Bergh, I.; Crichton, R.; Weltzien, E.; Ortiz, R.; Tumuhimbise, R. Gender and trait preferences for banana cultivation and use in Sub-Saharan Africa: A literature review. Econ. Bot. 2020, 74, 226-241. [CrossRef]

42. Risvik, E.; Rødbotten, M.; Veflen, N.O. Cross-Cultural Dimensions in Food Choice: Europe, Understanding Consumers of Food Products; Woodhead Publishing Ltd.: Cambridge, UK, 2006.

43. De Langhe, E. The Establishment of Traditional Plantain Cultivation in the African Rain Forest: A Working Hypothesis. Rethinking Agriculture; Denham, T.P., Irarte, J., Vrydaghs, L., Eds.; Left Coast Press: Walnut Creek, CA, USA, 2007; pp. 361-370.

44. Lazarevic, V. Encouraging brand loyalty in fickle generation Y consumers. Young Consum. 2012, 13, 45-61. [CrossRef]

45. Klopčič, M.; Slokan, P.; Erjavec, K. Consumer preference for nutrition and health claims: A multi-methodological approach. Food Qual. Prefer. 2020, 82, 103863. [CrossRef]

46. Kikulwe, E.M.; Wesseler, J.; Falck-Zepeda, J. Attitudes, perceptions, and trust. Insights from a consumer survey regarding genetically modified banana in Uganda. Appetite 2011, 57, 401-413. [CrossRef]

47. Sanya, L.N.; Sseguya, H.; Kyazze, F.B.; Diiro, G.M.; Nakazi, F. The role of variety attributes in the uptake of new hybrid bananas among smallholder rural farmers in central Uganda. Agric. Food Secur. 2020, 9, 1-13. [CrossRef]

48. Hoek, A.C.; Pearson, D.; James, S.W.; Lawrence, M.A.; Friel, S. Healthy and environmentally sustainable food choices: Consumer response to point-of-purchase actions. Food Qual. Prefer. 2017, 58, 94-106. [CrossRef]

49. Lähteenmäki, L.; Lampila, P.; Grunert, K.; Boztug, Y.; Ueland, Ǩ.; Lström, A. Impact of health-related claims on the perception of other product attributes. Food Policy 2010, 35, 230-239. [CrossRef]

50. Verbeke, W. Functional foods: Consumer willingness to compromise on taste for health? Food Qual. Prefer. 2006, 17, 126-131. [CrossRef]

51. La Trobe, H. Farmers' markets: Consuming local rural produce. Int. J. Consum. Stud. 2001, 25, 181-192. [CrossRef]

52. Dhamotharan, P.G.; Selvaraj, K.N. Determining consumer preference and willingness to pay for GI registered bananas. J. Intellect. Prop. Rights 2013, 18, 576-583.

53. Garnett, T.; Mathewson, S.; Angelides, P.; Borthwick, F. Policies and Actions to Shift Eating Patterns: What Works? A Review of the Evidence of the Effectiveness of Interventions Aimed at Shifting Diets in More Sustainable and Healthy Directions; Chatham House: London, UK, 2015. 
54. Jolly, C.M.; Bayard, B.; Awuah, R.T.; Fialor, S.C.; Williams, J.T. Examining the structure of awareness and perceptions of groundnut aflatoxin among Ghanaian health and agricultural professionals and its influence on their actions. J. Soc.-Econ. 2009, 38, 280-287. [CrossRef]

55. Sabran, M.R.; Jamaluddin, R.; Abdul Mutalib, M.S.; Abdul Rahman, N. Socio-demographic and socio-economic determinants of adults' knowledge on fungal and aflatoxin contamination in the diets. Asian Pac. J. Trop. Biomed. 2012, S1835-S1841. [CrossRef]

56. Silva, A.; Caro, J.C.; Magana-Lemus, D. Household food security: Perceptions, behavior and nutritional quality of food purchases. J. Econ. Psychol. 2016, 55, 139-148. [CrossRef]

57. Basan, R.J.P. Consumer preference of table banana quality by income groups in the Philippines: Hedonic price analysis. Asian J. Agric.Develop. 2016, 13, 21-34.

58. Kim, H.Y.; Chung, J.-E. Consumer purchase intention for organic personal care products. J. Consum. Mark. 2011, $28,40-47$.

59. Lange, C.; Issanchou, S.; Combris, P. Expected versus experienced quality: Trade-off with price. Food Qual. Prefer. 2000, 11, 289-297. [CrossRef]

60. Bruschi, V.; Teuber, R.; Dolgopolova, I. Acceptance and willingness to pay for health-enhancing bakery products-Empirical evidence for young urban Russian consumers. Food Qual. Prefer. 2015, 46, 79-91. [CrossRef]

61. Wang, O.; De Steur, H.; Gellynck, X.; Verbeke, W. Motives for consumer choice of traditional food and European food in mainland China. Appetite 2015, 87, 143-151. [CrossRef]

62. Köster, E.P. Diversity in the determinants of food choice: A psychological perspective. Food Qual. Prefer. 2009, 20, 70-82. [CrossRef]

63. Zepada, L.; Dela, D. Organic and local food consumer behaviour: Alphabet Theory. Int. J. Consum. Stud. 2009, 33, 697-705. [CrossRef]

64. Hooker, N.H.; Teratanavat, R. Dissecting qualified health claims: Evidence from experimental studies. Critic. Rev. Food Sci. Nutr. 2008, 48, 160-176. [CrossRef] [PubMed] 